
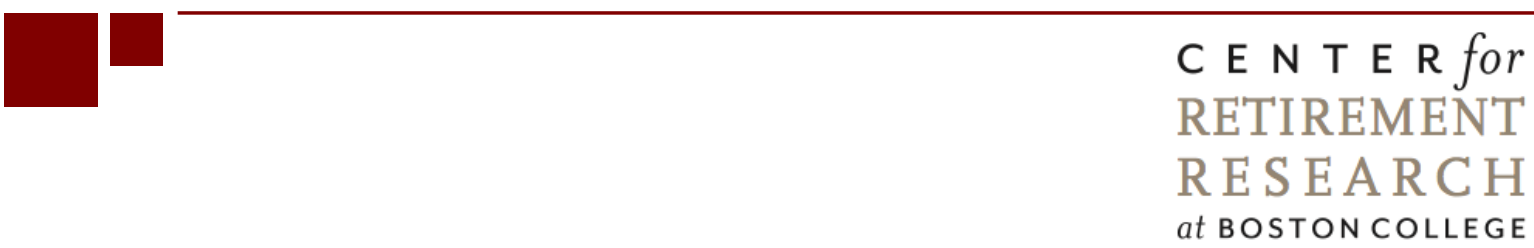

\title{
DOES AGE-RELATED DECLINE IN ABILITY CORRESPOND WITH RETIREMENT AGE?
}

\author{
Anek Belbase, Geoffrey T. Sanzenbacher, and Christopher M. Gillis
}

CRR WP 2015-24

September 2015

\author{
Center for Retirement Research at Boston College \\ Hovey House \\ 140 Commonwealth Avenue \\ Chestnut Hill, MA 02467 \\ Tel: 617-552-1762 Fax: 617-552-0191 \\ http://crr.bc.edu
}

\begin{abstract}
All of the authors are with the Center for Retirement Research at Boston College (CRR). Anek Belbase is a research project manager at the CRR. Geoffrey T. Sanzenbacher is a research economist at the CRR. Christopher M. Gillis is a research associate at the CRR. The research reported herein was performed pursuant to a grant from the U.S. Social Security Administration (SSA) funded as part of the Retirement Research Consortium. The opinions and conclusions expressed are solely those of the authors and do not represent the opinions or policy of SSA, any agency of the federal government, or Boston College. Neither the United States Government nor any agency thereof, nor any of their employees, makes any warranty, express or implied, or assumes any legal liability or responsibility for the accuracy, completeness, or usefulness of the contents of this report. Reference herein to any specific commercial product, process or service by trade name, trademark, manufacturer, or otherwise does not necessarily constitute or imply endorsement, recommendation or favoring by the United States Government or any agency thereof. The authors would like to thank Padmaja Ayyagari of the University of Iowa College of Public Health for helpful comments.
\end{abstract}

(C) 2015, Anek Belbase, Geoffrey T. Sanzenbacher, and Christopher M. Gillis. All rights reserved. Short sections of text, not to exceed two paragraphs, may be quoted without explicit permission provided that full credit, including (C) notice, is given to the source. 


\begin{abstract}
About the Center for Retirement Research
The Center for Retirement Research at Boston College, part of a consortium that includes parallel centers at the University of Michigan and the National Bureau of Economic Research, was established in 1998 through a grant from the Social Security Administration. The Center's mission is to produce first-class research and forge a strong link between the academic community and decision-makers in the public and private sectors around an issue of critical importance to the nation's future. To achieve this mission, the Center sponsors a wide variety of research projects, transmits new findings to a broad audience, trains new scholars, and broadens access to valuable data sources.
\end{abstract}

Center for Retirement Research at Boston College

Hovey House

140 Commonwealth Ave

Chestnut Hill, MA 02467

Tel: 617-552-1762 Fax: 617-552-0191

http://crr.bc.edu

Affiliated Institutions:

The Brookings Institution

Massachusetts Institute of Technology

Syracuse University

Urban Institute 


\begin{abstract}
While declines in physical and mental performance are inevitable as workers age, they are not uniform across the various systems of the body - some physical and cognitive abilities decline much earlier than others. This variance implies that workers in occupations that rely on skills that decline early may be unable to work until late ages, even as policy changes like increases in the Full Retirement Age (FRA) encourage them to. Researchers often estimate models of early retirement that include a control for whether a worker is in a blue-collar job basically assuming that less-physical white-collar work allows longer careers. But this assumption ignores the fact that even workers in white-collar occupations may find themselves relying on skills that have declined. This paper instead reviews the literature on aging and constructs a Susceptibility Index meant to reflect how susceptible an occupation is to declines in ability, regardless of whether the occupation relies on physical abilities (as blue-collar occupations do) or cognitive ones.
\end{abstract}

This paper finds that:

- A variety of white-collar occupations, such as police detective and designer, are just as susceptible to declines in the abilities required for work as are blue-collar occupations.

- The Susceptibility Index is a significant predictor of early retirement; for example, workers in occupations in the $90^{\text {th }}$ percentile of the Index are 5.7 percentage points more likely to retire by age 65 than workers in the $10^{\text {th }}$ percentile.

- When controlling for the Susceptibility Index, the commonly used categorization of blueor white-collar has no additional explanatory power in a model of early retirement.

The policy implications of this paper are:

- Blue-collar occupations are especially susceptible to early ability declines, so workers in these occupations are less likely to be able to work to the FRA as it increases to 67.

- In addition, some workers in white-collar occupations may have similar difficulty responding to FRA increases - a possibility that has been largely ignored to date. 


\section{Introduction}

Nobody can withstand the effects of time. With age, even among the fittest individuals, skin and arteries harden, reaction times slow, and immune function diminishes. While declines in physical and mental performance are inevitable, they are not uniform across the various systems of the body. This variance means that the different abilities used to perform tasks at work and at home decline at different rates as individuals age. ${ }^{1}$ For example, explosive strength (e.g. the ability to jump) declines significantly during one's working life, while static strength (e.g. the ability to hold up a weight) declines relatively little during the same period. ${ }^{2}$ Workers in occupations that rely on abilities that decline fastest are also likely to be at the greatest risk of retiring early. Most research on retirement timing attempts to proxy the possibility of early decline by controlling for whether a worker's occupation is blue or white collar - the basic assumption is that white-collar workers can work longer and blue-collar workers cannot. But is this distinction appropriate? Are all white-collar workers able to work well into their sixties and, if not, which occupations are most vulnerable? Are certain blue-collar jobs better than others in terms of allowing a long working life? Although these questions have implications for policymakers considering ways to encourage individuals to work longer, to date researchers have not identified a systematic way to fully account for the relationship between occupation and early retirement.

To address this issue, this paper presents a Susceptibility Index that measures how susceptible the abilities required by an occupation are to decline during the working years. The project draws inspiration from a "work-ability index" developed in Finland to measure municipal workers’ physical, mental, and psychological capacity to meet work demands and identify workers in need of occupational therapy. Several studies using this index reported significant heterogeneity in work ability across occupations among older workers (Ilmarinen and Klockars 1997; Ilmarinen, Tuomi and Seitsamo 2005). The goal of this project is to first construct an index that identifies occupations that place importance on abilities that decline early and then to explore whether workers in such occupations will retire earlier regardless of whether the occupation is white or blue collar.

\footnotetext{
${ }^{1}$ As one example, fluid intelligence (the ability to think logically) declines well in advance of crystalized intelligence (acquired knowledge). See Salthouse (2009).

${ }^{2}$ Spirduso, Francis, and MacRae, 2005.
} 
To construct the Index, the first step is a substantial review of the aging literature to identify which abilities, both cognitive and physical, decline by the early to mid-sixties. The second step is to construct the Index by using the Occupational Information Network (O*NET) database to evaluate occupations based on the number and importance of abilities required for the job - the higher the Index the more the occupation relies on abilities that decline early. The Index is then placed in a model of early retirement using the Health and Retirement Study (HRS) to better estimate how likely individuals in certain occupations are to retire early. The project compares how well this occupation-specific Index predicts early retirement relative to more standard measures, like being in blue- or white-collar occupations. As a sensitivity to see how well the Index explains other employment outcomes, in one specification the project replaces early retirement with the receipt of disability insurance prior to age 65 .

The Index represents a substantial improvement over the occupational information typically contained in studies of early retirement. Past research on retirement timing among American workers typically classified workers as blue or white collar. This classification does not account for the fact that, even within these broad occupational groups, levels of ability decline vary significantly. For example, food servers can often work well into their 60 s but roofers have trouble working past 50 - yet, both groups are considered blue collar. Other studies on American workers have found a correlation between the physical demands of an occupation and early retirement. However, these studies have not examined characteristics of occupations beyond gross physical demands, despite research that shows a heterogeneous, age-related decline in various physical and mental abilities (for example, Holden 1988; Iversen and Poulsen 2001; Karpansalo et. al. 2002).

Of course, occupation is not the only thing that determines a worker's ability to work longer, and ignoring these characteristics could lead to an overestimate of the role of the Index in measuring the susceptibility of workers in an occupation's to early retirement. A significant minority of older workers, through luck and lifestyle, will not experience a significant decline in ability relative to their job requirements. These workers are likely to remain productive in their jobs even in their late 60s and may select into occupations amenable to doing so. Workers in occupations that rely on accumulated knowledge and verbal ability, such as postsecondary teachers, are particularly likely to fall under this category (Skirbekk, 2008). Thus, controlling for 
individual cognitive ability (through education) is an important aspect of the early retirement model.

The results suggest that: 1) considerable variance exists, especially within white-collar occupations, in the importance of abilities that are known to show early decline; and 2) this variance, as captured by the Index, is predictive of early retirement. The predictive power of the Index exists when individual-level controls are included in the model and is greater than the more commonly used white- and blue-collar division. Overall, similar individuals in occupations sitting at the $90^{\text {th }}$ percentile of the Index (very susceptible to age-related decline) are 5.7 percentage points more likely than individuals at the $10^{\text {th }}$ percentile to retire before age 65. The Index is not only predictive of early retirement but also of disability receipt prior to age 65. Individuals at the $90^{\text {th }}$ percentile of the Index are 2.6 percentage points more likely than individuals at the $10^{\text {th }}$ percentile to receive disability insurance benefits; this difference is nontrivial since just 7.4 percent of our sample receives disability insurance at all. Because both white- and blue-collar workers face levels of susceptibility as high as the $90^{\text {th }}$ percentile, the Index provides a way to identify workers within these broad categories who may have difficulty responding to policy changes designed to encourage working longer (such as changes in the FRA).

\section{Constructing a Susceptibility Index}

To construct the Susceptibility Index described above, this project uses the Occupational Information Network (O*NET) database to measure occupation-related ability requirements. The O*NET surveys job-holders, occupational analysts, and occupational experts to measure the importance of each ability for each occupation. The O*NET Content Model identifies the importance of 51 abilities that contribute to a worker's capacity to do the job within each of over 900 occupations. These abilities include physical abilities (e.g., "Explosive Strength”, “Manual Dexterity”), cognitive abilities (e.g., “Deductive Reasoning”, “Memorization”), and sensory abilities (e.g., “Night Vision”, “Sound Localization”). The importance of these 51 abilities differs significantly across occupations. As is described in detail below, only some of these abilities are expected to decline substantially before workers hit their mid-sixties. Our hypothesis is that occupations that rely heavily on abilities known to decline prior to the mid- 
sixties will tend to retire early.

Identifying Abilities that Decline Early

To identify abilities that decline during working years, we rely on the literature from a wide range of fields, including gerontology, psychology, medicine, and occupational studies. This section is broken down into the four broadest categories contained in $\mathrm{O}$ *Net: Cognitive, Psychomotor, Physical, and Sensory.

\section{i) Cognitive Abilities}

The extent to which cognitive abilities decline with age generally depends on whether the cognitive ability in question benefits from accumulated knowledge or not. "Crystalized” cognitive ability, or knowledge (such as one's vocabulary), tends to accumulate well into one's sixties and even seventies. ${ }^{3}$ Older workers in occupations requiring extensive work-related knowledge to be productive will hold a productivity advantage over younger workers to the extent that the work-related knowledge in question is static.

On the other hand, “fluid” cognitive abilities, such as episodic memory, working memory, and reaction time - which people need to acquire new information and make decisions - steadily decline with age starting in one's twenties or thirties. ${ }^{4}$ This decline in fluid cognitive ability is observed at the neurological level, in controlled tests of cognitive ability, and in real world tasks that involve fluid cognitive ability. ${ }^{5}$ While a high degree of individual variation exists in the rate of decline in fluid cognitive ability, ${ }^{6}$ one's initial levels of ability, education, or occupation are not correlated with the rate of decline. ${ }^{7}$ The only factors consistently linked to the rate of cognitive change are exercise (correlated with slower decline) and poor health (diabetes and strokes are correlated with faster decline). ${ }^{8}$ Controlling for these factors in the model of early retirement will be important if the effect of occupation is to be isolated from the effect of individual characteristics on early retirement.

The O*NET measures the importance of seven broad types of cognitive abilities - verbal ability, spatial ability, ability to generate ideas and reason, attentiveness, quantitative ability,

\footnotetext{
${ }^{3}$ Schaie andWillis, 2010, Salthouse, 2009.

${ }^{4}$ Singh-Manoux et al, 2012.

${ }^{5}$ Salthouse, 2012, Gross et al, 2011.

${ }^{6}$ Ylikoski et al 1999.

${ }^{7}$ Yaffe, et al, 2009.

${ }^{8}$ Salthouse, 2009.
} 
memory, and perceptual abilities - for over 900 occupations. Within these categories, and in keeping with the discussion above, verbal and quantitative abilities (which generally reflect crystalized ability) do not decline significantly by age 60 for most individuals. On the other hand, spatial abilities, perceptual speed, and memory (which generally reflect fluid ability) tend to undergo measurable and practically significant decline by the end of most workers' careers. ${ }^{9}$ Table A1 in the Appendix provides a detailed breakdown of how each of the cognitive abilities was assigned the status of declining with age or not.

\section{ii) Psychomotor Abilities}

Psychomotor abilities function using a combination of cognitive (or neurological), physical, and sensory abilities. For example, arm-hand steadiness requires neurons to trigger muscles to react to changes in body position and visual cues. ${ }^{10}$ The O*NET categorizes psychomotor abilities into fine manipulative abilities, control movement abilities, and reaction time and speed. A review of the literature indicates that control movement abilities (e.g. the ability to walk in a coordinated manner) does not decline significantly during a typical career while fine manipulative abilities (e.g., the motions needed to sew) and reaction time and speed typically declines significantly as workers approach retirement-age. While some studies suggest fine manipulative abilities can be preserved through practice, declines in reaction time and speed do not appear to be possible to mitigate through practice. ${ }^{11}$ Table A2 in the Appendix provides a breakdown of whether each of the psychomotor abilities was assigned the status of declining with age or not.

\section{iii) Physical Abilities}

The O*Net divides physical abilities into four broad categories: strength, endurance, flexibility, and coordination. Strength declines with age, but not uniformly across activity types. This result stems from the fact that muscle fibers that are important when force must be maintained for long periods of time do not atrophy nearly as quickly as muscle fibers that are

\footnotetext{
${ }^{9}$ Craik and Salthouse, 2011.

${ }^{10}$ Spirduso, Francis, and MacRae, 2005.

${ }^{11}$ Verhaeghen, 2013, Czaja, S. J., \& Sharit, J. 1998.
} 
most useful in short bursts. ${ }^{12}$ Thus, strength declines tend to be slower for activities that require a force be held constant over a period of time (e.g., holding a grocery bag, supporting one’s body) than for activities that require quick exertions of force (e.g., throwing an object). The ability to exert force quickly - often called “explosive” force - is further compromised by a general reduction in the ability to coordinate muscles for quick actions. ${ }^{13}$ The nature of these declines suggests that a worker's ability to do jobs that rely on a static type of strength, whereby force is held constant, or that rely on the abdominal and back muscles (so-called "trunk strength”) to hold a position would not be compromised through the early 60s. This conclusion seems especially true since several studies have reported ways to stave off declines in static strength; use through work activity and resistance training have been shown to aid in the maintenance of static and trunk strength. ${ }^{14}$ Less evidence exists regarding the impact of training or work on reducing the effects of aging on explosive strength. ${ }^{15}$

An individual's endurance or stamina is largely determined by the functioning of his cardiovascular system. This system undergoes a number of changes that can, especially with inactivity, reduce the ability to function with age: arteries become stiffer; blood pressure increases; communication between the automatic nervous system and cardiovascular systems becomes slower; and maximal heart rate declines, as does the amount of blood pumped from the heart. ${ }^{16}$ However, the most common measures of these changes show that as long as an individual remains active the decline is very slow. Indeed, active individuals in their 60s have similar stamina as inactive individuals in their 30s. In other words, workers who use stamina in their jobs on a daily basis (e.g., dancers, firefighters) are unlikely to experience the declines with age that may be common for less active individuals. Endurance is not assumed to decline early. Flexibility refers to the range of motion a person has in their joints and is largely a function of the suppleness of tendons and ligaments that attach muscles to bone. Because tendons and ligaments lose water as people age, most measures of flexibility show substantial declines. One of the most extreme examples of flexibility decline with aging is spinal flexibility and trunk extension, both crucial components of being able to bend ones' body to meet the demands of

\footnotetext{
${ }^{12}$ Spirduso, Francis, and McRae (2005) provide an excellent summary of this research as well as discussion on Type I versus Type II muscle fibers. See Vandervoort (2002) for a discussion of differential muscle atrophy.

${ }^{13}$ Spirduso, Francis, and McRae (2005).

${ }^{14}$ For example, see Frontera et al. (1988) or Hagerman et al. (2001) for evidence related to strength gains in the quadriceps.

${ }^{15}$ Spirduso, Francis, and McRae (2005)

${ }^{16}$ Safar (1990), Fleg et al. (1985), Tanaka et al. (2001), Lakatta (2002).
} 
work or daily activity. The sit-and-reach test, which measures spinal flexibility, shows declines of 15 percent per decade between the ages of 30 and 70, and losses in trunk extension are larger. ${ }^{17}$ Furthermore, the evidence is mixed on whether age-related reductions in flexibility can be mitigated with exercise or use, and so it is unclear at this point that individuals working in occupations that demand flexibility (e.g., roofing, plumbers) will maintain it better than those in occupations that do not. ${ }^{18}$ For these reasons, it is assumed that all measures of flexibility included in the $\mathrm{O} *$ Net data show early decline.

Finally, an individual's ability to balance themselves and coordinate movement involves a complicated mixture of sensory and cognitive abilities, physical strength, and flexibility. Regarding the sensory systems, age-related declines clearly affects the ability to balance. An individual's vision (which will be discussed in more detail below) changes in several ways that influence balance and coordination: depth perception is reduced, the individual becomes more sensitive to glare, and the vision field narrows. ${ }^{19}$ Older individuals also have a reduced sense of touch. ${ }^{20}$ Finally, the vestibular system, which is an extremely important contributor to balance and coordination by helping the body understand its position, reduces functionality as people age. $^{21}$ As mentioned above, flexibility declines early as well. In other words, an older individual's balance and coordination are compromised by a reduced ability to see and feel where they are in space and to move their body freely to make adjustments. Because changes with age in the sensory system are difficult to mitigate with physical activity or work, it seems likely workers’ ability to do jobs where balance and coordination are important will be compromised. Table A3 in the Appendix provides a breakdown of whether each of the physical abilities was assigned the status of declining with age or not.

\section{iv) Sensory Abilities}

Vision, hearing, and speech also play essential roles in some occupations, and the O*Net provides detail on the importance of each. Although vision obviously declines as an individual ages, with correction many aspects of vision can be maintained. In general, both near vision, far vision, and color discrimination can be maintained (with correction as necessary) well into an

\footnotetext{
${ }^{17}$ Golding and Lindsay (1989).

${ }^{18}$ For example, see discussion in Stathokostas et al. (2013).

${ }^{19}$ Bell (1972), Higgins (1988), Fozard (1990), and Fozard and Gordon-Salant (2001).

${ }^{20}$ Bruce (1980).

${ }^{21}$ Rosenhall and Ruben (1975).
} 
individual's seventies. ${ }^{22}$ Other aspects of the visual system are less easy to correct and do show early declines. For example, because pupils shrink and do not dilate as quickly as people age, older individuals typically have worse night vision and are more sensitive to glare than others. ${ }^{23}$ Additionally, the field of vision decreases, reducing peripheral vision. ${ }^{24}$ Finally, several studies have shown that the ability to perceive depth declines quickly with age. ${ }^{25}$ The O*Net includes seven measures of visual ability: far vision, near vision, color discrimination, night vision, peripheral vision, depth perception, and glare sensitivity. Due to the ability to correct, near and far vision are assumed not to decline early. Neither is visual color discrimination. However, night vision, peripheral vision, depth perception, and glare sensitivity are all assumed to decline early.

In general, auditory and speech abilities are relatively well maintained throughout an individual's working life. Hearing sensitivity certainly declines with age, but not in any significant way until after age $70 .{ }^{26}$ Similarly, speech recognition and speech clarity also decline with age, but not until much later in an individual's life. ${ }^{27}$ Perhaps the only auditory or speech ability that does decline relatively early is the ability to locate sound. In one study, individuals ages 45-66 showed a significant decline in the ability to locate sound horizontally. Thus, of the five $\mathrm{O}$ *Net abilities related to hearing and speech - hearing sensitivity, auditory attention, sound localization, speech recognition, and speech clarity - only sound localization is assumed to show early decline. Table A4 in the Appendix provides a breakdown of whether each of the sensory abilities was assigned the status of declining with age or not.

\section{Constructing the Index}

To construct the Index, the project merges the results from the literature review onto data contained in $O^{*}$ Net on the importance (scaled between 1 and 5) of those 52 attributes across 923 unique occupations. The purpose of the Index is to give occupations an ordering reflecting both the number of abilities the occupation relies on that decline and on the importance of those

\footnotetext{
${ }^{22}$ Fozard (1990). It is worth noting there is some disagreement as to how quickly color vision declines - for example, see Schieber (2006).

${ }^{23}$ Higgins (1988), Harrison (1993), Jackson et al (1997), Jackson and Owsley (2000), and Schieber (2006).

${ }^{24}$ Fozard and Salant (2001).

${ }^{25}$ Bell (1972) and Fozard (1990).

${ }^{26}$ Fozard and Gordon-Salant (2001), Gordon-Salant (2005).

${ }^{27}$ For example, Fozard and Gordon-Salant (2001), Gordon-Salant (2005) find large declines only in individuals over age 80 .
} 
abilities. The construction of the Index proceeds in five steps, laid out below for the hypothetical example of budget analysts:

\begin{tabular}{|l|l|}
\hline Description & Hypothetical example for "Budget Analysts" \\
\hline $\begin{array}{l}\text { Step 1: Identify abilities important to the } \\
\text { occupation as abilities that receive an } O^{*} \text { Net } \\
\text { importance score of 3 or over. }\end{array}$ & $\begin{array}{l}\text { For Budget Analysts, } 12 \text { of the } 52 \text { abilities } \\
\text { recorded by O*Net have this importance level, } \\
\text { including “Deductive Reasoning," "Oral } \\
\text { Comprehension," and "Information Ordering." }\end{array}$ \\
\hline $\begin{array}{l}\text { Step 2: Apply from Tables A1 to A4 the } \\
\text { important abilities that decline early in a } \\
\text { worker's career }\end{array}$ & $\begin{array}{l}\text { For Budget Analysts, 3 of the 12 important } \\
\text { abilities decline this quickly. }\end{array}$ \\
\hline $\begin{array}{l}\text { Step 3: Determine the aggregate importance } \\
\text { score for the abilities identified in Step 2 by } \\
\text { summing the } O * N e t \text { importance scores for } \\
\text { those abilities. }\end{array}$ & $\begin{array}{l}\text { For Budget Analysts, this score is the sum of } \\
\text { the importance scores for the 3 important } \\
\text { abilities identified in Step 2. Two had scores of } \\
5 \text { and one of 4, so the sum is } 14 .\end{array}$ \\
\hline $\begin{array}{l}\text { Step 4: Identify the aggregate importance } \\
\text { score for all abilities identified in Step 1 by } \\
\text { summing the } O * N e t \text { importance scores for } \\
\text { those abilities. }\end{array}$ & $\begin{array}{l}\text { For Budget Analysts, this score is the sum of } \\
\text { the } 12 \text { importance scores identified in Step 1. } \\
\text { These scores sum to 50. }\end{array}$ \\
\hline $\begin{array}{l}\text { Step 5: Calculate the Susceptibility Index as } \\
\text { the ratio of the sum calculated in Step } 3 \text { and } \\
\text { the sum calculated in Step 4. }\end{array}$ & $\begin{array}{l}\text { For Budget Analysts, the Susceptibility Index is } \\
14 / 50 \text { or 28 percent. }\end{array}$ \\
\hline
\end{tabular}

Once the Index is constructed, each occupation is assigned its percentile among all the occupations considered by $\mathrm{O} *$ Net. Figure 1 shows the percentile position of 20 occupations in the HRS, and Table 1 provides some descriptive statistics comparing white- to blue-collar occupations. Importantly, white-collar occupations are represented not only in the low range (as expected) but also in the high range of the Index. Indeed, as shown in Table 1, 9.9 percent of workers in white-collar occupations are above the $75^{\text {th }}$ percentile of the Index; less than the 55.9 percent for blue-collar occupations, but still substantial. This fact confirms that blue-collar occupations are likely harder to work at as individuals get older. However, Table 1 also reflects a main contention of this paper: not all occupations within the broad white- and blue-collar categories are created equally in terms of the abilities they use and those abilities rate of decline with age. Does this variance translate to earlier retirement amongst workers in these 
occupations? To answer that question, the paper next embeds the Index in a standard early retirement model.

\section{A Model of Early Retirement}

To incorporate the Index into a model of early retirement, this paper uses data from waves 1-11 of the HRS, collected between 1992 and 2012. In this draft of the paper, "early” retirement” is defined variously as: 1 ) retirement before age 63; 2) retirement before age 65; and retirement before age 67. In each of these specifications, retirement is defined as the first wave in which an individual claims to be "fully" retired. We choose each age for its importance in relation to Social Security. By looking at individuals who retire before 63, we allow everyone in the sample to work until and then retire during their first year of the Social Security eligibility. The following ages - 65 and 67 - represent old and future FRAs. Our definition of "early retirement” looks at individuals who come up short of both of these dates. The sample consists of all individuals working at the interview closest to their $58^{\text {th }}$ birthday (the “age-58 interview”) and who reach the age of early retirement by $2012 .^{28}$

To examine how the Index predicts other economic outcomes, we also incorporate it into a model of entry into the federal disability program, again using data from waves 1-11 of the HRS. Here, disability is defined as receiving Supplemental Security Income (SSI) or Social Security Disability Insurance (SSDI) at any time between the waves closest to the individual's $55^{\text {th }}$ and $65^{\text {th }}$ birthdays. For this sensitivity, we use the age-55 interview to identify an individual's occupation, because this earlier age allows those who may not be working at their age-58 interview because of their SSI/SSDI receipt to be included in the analysis.

Table 2 separately provides descriptive statistics on the sample being used in the analysis for workers in occupations in the bottom 50 percent of the Index and those in the top 50 percent. Among other things, workers in occupations in the bottom 50 percent are better educated, earn more, and are less likely to be a minority than workers in the top. This result stems from the fact that white-collar occupations are more likely to be in the bottom 50 percent of the Susceptibility Index and white-collar workers are more educated. Table 2 illustrates the importance of controlling for individual-level effects in the early retirement model. Table 2 also shows very

\footnotetext{
${ }^{28}$ If an individual is not working at their age-58 interview, they are excluded from the analysis to maintain the distance between the time an individual is observed in an occupation and the various measures of early retirement.
} 
clearly that workers in the top 50 percent are more likely to retire before all three selected retirement ages, and are more likely to receive SSI or SSDI.

Because the publicly available HRS data do not contain the detailed occupational codes needed to merge the Index onto individual workers, restricted Social Security Administration administrative occupation data is used to combine the 2010 version of the Occupational Information Network (O*NET) database with the HRS. This merge is conducted by creating an occupation code cross-walk between the 1980, 1998, 2002, and 2010 census codes (used in different waves of the HRS restricted data) and the 2010 Standard Occupational Codes (SOC, used in the $\mathrm{O}^{* \mathrm{NET}}$ ). The end result of this merge is that each working individual, except for the 9 percent of workers for whom a match between $\mathrm{O} *$ Net and the HRS occupation was unsuccessful, has the Index assigned for both their age-58 and their age-55 occupation.

Aside from the Index, our empirical model will also include controls for individual-level demographic and job characteristics that may alter the retirement date. These controls include a vector of demographic and other "initial” characteristics associated with the individual's age-58 job for the early retirement model and the age-55 job for the disability-entry sensitivity. The demographic variables include an individual's education (less than high school, high school graduate, some college), race, Hispanic origin, gender, and region. Variables related to the individual's employment status include self-employment, indicators for the presence of a DB or DC pension at a prior job. We also include controls for an individual's health, which has an obvious impact on their retirement date. To gauge a person's health, we create indicator variables for 13 health conditions that are asked in each wave of the HRS and add them up at the individual's age-58 or age-55 interview to create a health index taking on a value of 0 (best health) to 13 (worst health). ${ }^{29}$

To control for the possibility that certain aspects of a worker's life unrelated to their occupation change between age-58 or age-55 (when their occupation is identified) and the early retirement date, the empirical approach will also control for certain "shocks." These shocks include changes in the health index, a layoff or business closing, or a spouse's illness or

\footnotetext{
${ }^{29}$ These 13 conditions include eight health conditions and five limitations to activity of daily living. The health conditions included are: 1) "high blood pressure with medication”; 2) "diabetes with insulin”; 3) "cancer of any kind, seeing doctor”; 4) "activity limiting lung disease”; 5) "heart condition, taking medication”; 6)

"emotional/psychological problems"; 7) "stroke with problems afterward"; and 8) "arthritis with medication". The limitations to activities of daily living are: 1) "needs help bathing”; 2) "needs help getting dressed”; 3) "needs help eating"; 4) "needs help using a map"; and 5) "needs help walking”. A similar index, albeit using a slightly different set of health indicators, was used by Dwyer and Mitchell (1999).
} 
retirement. Controlling for these events, which may lead to early retirement and also may be correlated with occupation, ensures that the effect of the Index is limited to the effect of occupation on retirement and does not include changes workers in those occupations are more likely to experience.

Probit regressions were estimated for three measures of early retirement and for disability entry, taking the forms:

$$
\begin{gathered}
\varphi\left(Y_{i}\right)=\alpha_{0}+\alpha_{1} S I_{i, j}+\gamma X_{i}+\varepsilon_{i} \\
\varphi\left(Z_{i}\right)=\beta_{0}+\beta_{1} S I_{i, j}+\theta X_{i}+\varepsilon_{i}
\end{gathered}
$$

where $Y_{i}$ indicates one of the three measures of retirement timing being studied and $Z_{i}$ indicates the measure of disability entry. The variable $S I_{i, j}$ is the Susceptibility Index in occupation $j$ for the individual's job closest to age 58 or age 55, depending on the dependent variable. Thus, the coefficient of interest is $\alpha_{1}$ or $\beta_{1}$, which indicates the effect of the Susceptibility Index on early retirement or disability claiming. The vector of variables represented by $X_{i}$ is meant to capture the controls described above (both the initial conditions and the shocks).

\section{Results}

The regression results presented in Tables 3a, 3b, and 3c are for early retirement prior to age 63, age 65, and age 67, respectively. Each table presents three specifications of the model: 1) without any controls; 2) with a blue-collar dummy and controls for demographic variables; and 3) with all other controls (remaining initial conditions and shocks). Importantly, the Index is a significant predictor of earlier-than-planned retirement in most of the model's specifications, with the exception of the age 63 regressions. The results reported are marginal effects and so can be interpreted as the percentage-point increase on the probability of early retirement for a 1 percentile change in the Index. Looking at the specification that uses full controls, an increase of 10 percentiles in the Index increases the probability of retiring before age 63, 65, and 67 by 0.24 , 0.71 , and 0.74 percentage points, respectively. This means workers in occupations in the $90^{\text {th }}$ percentile of the Index are 5.7 percentage points more likely to retire before age 65 than 
individuals in the $10^{\text {th }}$ percentile, even controlling for demographic, health, and other individual characteristics.

The last two specifications also include the more standard control of whether the individual's occupation was white- or blue-collar. In the second specification-which controls only for the occupation dummy and demographic variables_-blue-collar is statistically significant at each age. The Index is significant for the older two ages, and blue-collar, while remaining significant, loses some of its explanatory power in relation to the Index. In the third specification, the results show that blue-collar has no significant explanatory power beyond what is captured by the Index-i.e., the Index captures at least the information contained in this, more standard, variable.

The other controls have intuitive interpretations. Individuals who are more educated, male, and in jobs that provide health insurance and pensions at age-58 are less likely to retire early. People who are in worse health at their age-58 job are also significantly more likely to retire before the various benchmarks than are healthier workers. Regarding the shock variables, workers whose health deteriorates, who lose their job through a layoff or business closing, or whose spouse retires prior to the retirement age being studied are also more likely to retire early. These intuitive results confirm that many individual characteristics beyond occupation can lead to early retirement. However, the results suggest that even when controlling for the various reasons someone may be forced to retire earlier than the selected Social Security benchmarks, their occupation still matters considerably.

Once estimates of the early retirement model are obtained, a useful way to put them in context is to examine how different the share of individuals retiring early would be if certain groups of workers had different Index values. This exercise can be accomplished by plugging in the estimates from the model, but using a "counterfactual" value of the index:

$$
\widehat{p r_{l}}=\widehat{\alpha_{0}}+{\widehat{\alpha_{1}}} S I_{i, j}^{\prime}+\check{\gamma} X_{i}+\varepsilon_{i}
$$

where $S I^{\prime}{ }_{i, j}$ is equal to an alternative value of the Susceptibility Index, $\widehat{\alpha_{0}}, \widehat{\alpha_{1}}$, and $\check{\gamma}$ are the estimates obtained in Tables 3a to 3c, and $X_{i}$ are the individuals demographic characteristics. Table 4 show the results of one such set of counterfactuals, where for each group of workers the Index is changed from its actual value to the $25^{\text {th }}$ percentile. The first column shows the actual 
predicted share retiring early for each group. Importantly, as we move from the top of the table (those in occupations not very susceptible to ability declines) to the bottom (those in susceptible occupations), the actual predicted share increases for two reasons: 1) the Susceptibility Index is increasing; and 2) the individuals in the group are more likely to retire early for the other reasons included in the regressions. The second column eliminates the first source of variation by assuming that everyone has a Susceptibility Index in the $25^{\text {th }}$ percentile, leaving only the differences in terms of individual characteristics or the shocks.

As an example of the effect of being in an occupation with a high Susceptibility Index, consider the row of Table 4 related to those in an occupation with an Index in the $80^{\text {th }}$ to $90^{\text {th }}$ percentile. If these individuals instead had an Index in the $25^{\text {th }}$ percentile, just 81.4 percent would retire before age 67 instead of the actual number of 86.6 percent. This represents a reduction of 5.2 percentage points over the real world. These counterfactuals illustrate the importance of occupation in determining retirement age. Importantly, occupations in the $80^{\text {th }}$ to $90^{\text {th }}$ percentile include several white-collar occupations, such as police detectives and airline pilots. In a model that included only the standard controls of white- and blue-collar, these individuals would be assumed to have the same retirement pattern as other white-collar workers, an assumption that turns out to be false. This observation carries with it one of the primary lessons of this paper - that some non-blue-collar workers may be unable to respond to increases in the FRA by working longer, because their occupations require abilities that show early decline.

To see if the Index is predictive of other economic outcomes, Table 5 presents the same three specifications as Tables 3a, 3b, and 3c but with SSI/SSDI receipt as the dependent variable and with time-sensitive controls from the age-55 interview instead of age-58 interview. We find a positive and significant relationship between the Susceptibility Index percentile and receiving SSI or SSDI when we control for nothing (first specification) and when we control for bluecollar status and demographic characteristics (second specification). Here, a 10-percentile increase in the Susceptibility Index increases the probability of receiving disability benefits by 0.31 percentage points, all else equal. This increase is non-trivial, since just 7.5 percent of our sample uses SSI/SSDI. In the final specification of the model, however, the Index is not significant, implying that other factors (e.g. health) are more important in determining the receipt of disability benefits than an individual's occupation. Given that the nature of the disability 
program is that it supports individuals experiencing health shocks that prohibit work, this result makes sense.

\section{Conclusion}

Standard models of early retirement divide individuals into white- and blue-collar workers. The logic is that workers in blue-collar occupations are typically involved in physical work that can't be done once they're older. While this assumption is partially true, this paper has shown through construction of a Susceptibility Index that a variety of white-collar occupations are also susceptible to early declines in the ability to work and that a variety of blue-collar occupations are not. Indeed, once the Susceptibility Index is included in early retirement and disability entry regressions, the commonly used variable of blue- or white-collar is not statistically significant. This fact indicates that it not so much whether a job is blue- or whitecollar, but instead whether or not the job uses abilities that decline during a worker's life. It just so happens that blue-collar jobs, on average, are more likely to fall into this category.

The results show that those workers in occupations in the $90^{\text {th }}$ percentile of the Index are 5.7 percentage points more likely than those in the $10^{\text {th }}$ percentile to retire before age 65 and are 5.9 percentage points more likely to retire before 67 . This result persists whether or not controls are included for demographics and health. Also, while not universally significant, the results suggest a positive relationship between the Index and the entry into the SSI or SSDI disability programs.

These results have important implications for policymakers. First, workers in blue-collar occupations are indeed more likely to retire early than other workers. The skills their jobs require do decline more rapidly, on average, than the skills white-collar workers use.

Policymakers should consider the ramifications of changes like FRA increases on the finances of older blue-collar workers - these workers may not be able to respond by working longer. Yet, this first lesson was largely known already. Just as importantly, policymakers must also consider the ability of certain white-collar workers to work longer in occupations such as police detective and licensed practicing nurse, both of which rely on many of the dynamic cognitive skills known to decline early. The analysis in the paper suggests that these workers may have difficulty working longer in response to policy changes, even though they are often grouped with people who can. This paper shows that a careful understanding of the abilities used by each occupation 
and their tendency to decline (or not) with age can put a finer point on any analysis of early retirement. 


\section{References}

Bell, Benjamin, Ernst Wolf, and Charles D. Bernholz. 1972. "Depth Perception as a Function of Age.” Faculty Publications, UNL Libraries. Paper 93.

Bruce, Margaret F. 1980. "The Relation of Tactile Thresholds to Histology in the Fingers of the Elderly.” Journal of Neurology, Neurosurgery, and Psychiatry 43(8): 730-734.

Chirikos, Thomas N. and Gilbert Nestel. 1991. "Occupational Differences in the Ability of Men to Delay Retirement.” Journal of Human Resources 26(1): 1-26.

Craik, Fergus I. M. and Timothy A. Salthouse. 2008. The Handbook of Aging and Cognition, 3. New York, NY: Psychology Press.

Czaja, Sara J. and Joseph Sharit. 1998. “Ability-Performance Relationships as a Function of Age and Task Experience for a Data Entry Task.” Journal of Experimental Psychology: Applied 4(4): 332-351.

Dayanidhi, Sudarshan. 2012. "Behavioral, Muscular and Dynamical Changes in Low Force Dexterous Manipulation During Development and Aging.” Doctoral dissertation, University of Southern California: Los Angeles, CA.

Dayanidhi, Sudarshan and Francisco J. Valero-Cuevas. 2014. "Dexterous Manipulation Is Poorer at Older Ages and Is Dissociated From Decline of Hand Strength.” The Journal of Gerontology Series A: Biological Sciences and Medical Sciences 69(9): 1139-1145.

Fillit, Howard M., Robert N. Butler, Alan W. O'Connell, Marilyn S. Albert, James E. Birren, Carl W. Cotman, William T. Greenough, Paul E. Gold, Arthur F. Kramer, Lewis H. Kuller, Thomas T. Perls, Barbara G. Sahagan, and Tim Tully. 2002. “Achieving and Maintaining Cognitive Vitality with Aging.” In Mayo Clinic Proceedings 77(7): 681-696. New York, NY: Elsevier.

Fleg, J.L., S.P. Tzankoff, and Edward G. Lakatta. 1985. “Age-Related Augmentation of Plasma Catecholamines During Dynamic Exercise in Healthy Males.” Journal of Applied Physiology 59(4): 1033-1039.

Fozard, James L. 1990. "Vision and Hearing in Aging.” In Handbook of the Psychology of Aging 6, edited by James Birren and K. Warner Schaie, 150-159. Houston, TX: Gulf Professional Publishing.

Fozard, James L. and Sandra Gordon-Salant. 1990. "Changes in Vision and Hearing with Aging.” In Handbook of the Psychology of Aging 6, edited by James Birren and K. Warner Schaie, 150-159. Houston, TX: Gulf Professional Publishing. 
Fozard, James L. and Sandra Gordon-Salant. 2001. "Changes in Vision and Hearing with Aging.” In Handbook of the Psychology of Aging 5, edited by James Birren and K. Warner Schaie, 241-266. Houston, TX: Gulf Professional Publishing.

Frontera, Walter R., Carol N. Meredith, Kevin P. O’Reilly, Howard G. Knuttgen, and William J. Evans. 1988. "Strength Conditioning in Older Men: Skeletal Muscle Hypertrophy and Improved Function.” Journal of Applied Physiology 64(3): 1038-1044.

Golding, Lawrence A. and Anne Lindsay. 1989. “Flexibility and Age.” Perspective 15(6): 28-30.

Gordon-Salant, Sandra. 2005. "Hearing Loss and Aging: New Research Findings and Clinical Implications.” Journal of Rehabilitation Research \& Development 42(4): 9-24.

Gross, Alden, George W. Rebok, Frederick W. Unverzagt, Sherry L. Willis, and Jason Brandt. 2011. "Word List Memory Predicts Everyday Function and Problem-Solving in the Elderly: Results from the ACTIVE Cognitive Intervention Trial.” Aging, Neuropsychology, and Cognition 18(2): 129-146.

Hagerman, Fredrick C., Seamus J. Walsh, Robert S. Staron, Robert S. Hikida, Roger M. Gilders, Thomas F. Murray, Kumika Toma, and Kerry E. Ragg. 2000. "Effects of High-Intensity Resistance Training on Untrained Older Men. I. Strength, Cardiovascular, and Metabolic Responses.” Journal of Gerontology 55(7): B336-B346.

Hambrick, David Z. and Randall W. Engle. 2002. "Effects of Domain Knowledge, Working Memory Capacity, and Age on Cognitive Performance: An Investigation of the Knowledge Is-Power Hypothesis.” Cognitive Psychology 44(4): 339-387.

Harrison, Joseph M., Raymond A. Applegate, J. Terry Yates, and Charles Ballentine. 1993. "Contrast Sensitivity and Disability Glare in the Middle Years." Journal of the Optical Society of America 10(8): 1849-1855.

Hayward, Mark D., William R. Grady, Melissa A. Hardy, and David Sommers. 1989. "Occupational Influences on Retirement, Disability, and Death." Demography 26(3): 393-409.

Higgins, Kent E., Myles J. Jaffe, Rafael C. Caruso, and Francisco M. deMonasterio. 1988. "Spatial Contrast Sensitivity: Effects of Age, Test-Retest, and Psychophysical Method." Journal of the Optical Society of America 5(12): 2173-2180.

Holden, Karen C. 1988. "Physically Demanding Occupations, Health, and Work After Retirement: Findings from the New Beneficiary Survey.” Social Security Bulletin 51(11): 3-15.

Ilmarinen, Juhani, Kaija Tuomi, and Matti Klockars. 1997. "Changes in Work Ability of Active Employees Over an 11-Year Period.” Scandinavian Journal of Work Environment and Health 23(1): 49-57. 
Ilmarinen, Juhani, Kaija Tuomi, and Jorma Seitsamo. 2005. "New Dimensions of Work Ability.” In International Congress Series 1280 3-7. New York, NY: Elsevier.

Jackson, Gregory R. and Cynthia Owsley. 2000. "Scotopic Sensitivity During Adulthood.” Vision Research 40(18): 2467-2473.

Jackson, Gregory R., Cynthia Owsley, and Gerald McGwin Jr. 1999. “Aging and Dark Adaptation.” Vision Research 39(23): 3975-3982.

Karpansalo, Minna, Pirjo Manninen, Timo A. Lakka, Jussi Kauhanen, Rainer Rauramaa, and Jukka T. Salonen. 2002. "Physical Workload and Risk of Early Retirement: Prospective Population Based Study Among Middle-Aged Men.” Journal of Occupational and Environmental Medicine 44(10): 930-939.

Lakatta, Edward G. 2002. "Age-Associated Cardiovascular Changes in Health: Impact on Cardiovascular Disease in Older Persons.” Heart Failure Reviews 7(1): 29-49.

Lund, Thomas, Lars Iversen, and Kjeld B. Poulsen. 2001. "Work Environment Factors, Health, Lifestyle and Marital Status as Predictors of Job Change and Early Retirement in Physically Heavy Occupations.” American Journal of Industrial Medicine 40(2): 161169.

Metter, E. Jeffrey, Robin Conwit, Jordan Tobin, and James L. Fozard. 1997. “Age-Associated Loss of Power and Strength in the Upper Extremities in Women and Men." The Journals of Gerontology Series A: Biological Sciences and Medical Sciences 52(5): B267-B276.

Nunes, Ashley and Arthur F. Kramer. 2009. "Experience-Based Mitigation of Age-Related Performance Declines: Evidence from Air Traffic Control.” Journal of Experimental Psychology Applied 15(1): 12-24.

Pohjonen, Tiina. 2001. "Perceived Work Ability of Home Care Workers in Relation to Individual and Work-Related Factors in Different Age Groups.” Occupational Medicine 51(3): 209-217.

Rosenhall, Ulf and Wallace Rubin. 1975. "Degenerative Changes in the Human Vestibular sensory epithelia.” Acta Otolaryngolica 79(1-2): 67-81.

Safar, Michel. 1990. “Ageing and its Effects on the Cardiovascular System.” Drugs 39(1): 1-8.

Salthouse, Timothy. 2010. Major Issues in Cognitive Aging. Oxford, UK: Oxford University Press.

Salthouse, Timothy. 2012. "Consequences of Age-Related Cognitive Declines.” Annual Review of Psychology 63: 201-226. 
Schaie, K. Warner, and Sherry L. Willis. 2010. Handbook of the Psychology of Aging, 7e. Waltham, MA: Academic Press.

Schieber, Frank. 2006. "Vision and Aging.” In Handbook of the Psychology of Aging 6, edited by James Birren and K. Warner Schaie, 150-159. Houston, TX: Gulf Professional Publishing.

Singh-Manoux, Archana, Mika Kivimaki, M. Maria Glymour, Alexis Elbaz, Claudine Berr, Klaus P. Ebmeier, Jane E. Ferrie, and Aline Dugravot. 2012. "Timing of Onset of Cognitive Decline: Results from Whitehall II Prospective Cohort Study.” British Medical Journal 344: 7622.

Skirbekk, Vegard. 2008. "Age and Productivity Capacity: Descriptions, Causes and Policy Options.” Ageing Horizons 8: 4-12.

Spirduso, Waneen W., Karen L. Francis, and Priscilla G. MacRae. 2005. Physical Dimensions of Aging. $2^{\text {nd }}$ ed. Champaign, IL: Human Kinetics.

Stathokostas, Liza, Matthew W. McDonald, Robert M. D. Little, and Donald H. Paterson. 2013. "Flexibility of Older Adults Aged 55-86 Years and the Influence of Physical Activity." Journal of Aging Research 2013(1): 1-8.

Tanaka, Hirofumi, Kevin D. Monahan, and Douglas R. Seals. 2001. “Age-Predicted Maximal Heart Rate Revisited.” Journal of the American College of Cardiology 37(1): 153-156.

Vandervoort, Anthony A. 2002. “Aging of the Human Neuromuscular System.” Muscle \& Nerve 25(1): 17-25.

Verhaeghen, Paul. 2013. The Elements of Cognitive Aging: Meta-Analyses of Age-Related Differences in Processing Speed and Their Consequences. Oxford, UK: Oxford University Press.

Waiter, Gordon D., Helen C. Fox, Alison D. Murray, John M. Starr, Roger T. Staff, Victoria J. Bourne, Lawrence J. Whalley, and Ian J. Deary. 2008. "Is Retaining the Youthful Functional Anatomy Underlying Speed of Information Processing a Signature of Successful Cognitive Ageing? An Event-Related fMRI Study of Inspection Time Performance. Neuroimage 41(2): 581-595.

Yaffe, Kristine, Alexandra J. Fiocco, Karla Lindquist, Eric Vittinghoff, Eleanor M. Simonsick, Anne B. Newman, and Tamara B. Harris. 2009. "Predictors of Maintaining Cognitive Function in Older Adults: The Health ABC Study.” Neurology 72(23): 2029-2035.

Ylikoski, Raija, Ari Ylikoski, Pertti Keskivaara, Reijo Tilvis, Raimo Sulkava, and Timo Erkinjuntti. 1999. "Heterogeneity of Cognitive Profiles in Aging: Successful Aging, Normal Aging, and Individuals at Risks for Cognitive Decline.” European Journal of Neurology 6(6): 645-652. 
Table 1. Variation in Susceptibility Index Percentiles by Occupation Type

\begin{tabular}{lcc}
\hline & White collar & Blue collar \\
\hline Mean Susceptibility Index percentile & $36.8 \%$ & $78.5 \%$ \\
Share below 25\% & 37.6 & 0.4 \\
Share above 75\% & 9.9 & 55.9 \\
\hline
\end{tabular}

Source: Authors' calculations from the Health and Retirement Study, 1992-2012 waves. 
Table 2. Descriptive Statistics by Susceptibility Index Percentile

\begin{tabular}{|c|c|c|}
\hline Variable & Bottom 50\% & Top 50\% \\
\hline Retired before 63 & $49.0 \%$ & $52.8 \%$ \\
\hline Retired before 65 & 64.9 & 70.4 \\
\hline Retired before 67 & 80.3 & 85.4 \\
\hline Disability claimed before 65 & 5.4 & 9.5 \\
\hline Female & 60.8 & 40.4 \\
\hline Male & 39.2 & 59.6 \\
\hline Less than high school & 7.1 & 33.1 \\
\hline High school & 34.2 & 44.2 \\
\hline College & 58.6 & 22.7 \\
\hline Black & 10.7 & 21.0 \\
\hline White & 89.3 & 79.0 \\
\hline Hispanic & 4.6 & 10.8 \\
\hline Married & 77.4 & 75.4 \\
\hline Health Index & 0.9 & 1.0 \\
\hline Health insurance & 68.9 & 63.6 \\
\hline Current earnings & $\$ 49,752.9$ & $\$ 35,018.8$ \\
\hline Number of observations & 2,511 & 2,547 \\
\hline
\end{tabular}

Source: Authors' calculations from the Health and Retirement Study, 1992-2012 waves. 
Table 3A. Probit Regression Estimating Retirement by Age 63

\begin{tabular}{|c|c|c|c|}
\hline Variables & $\begin{array}{l}\text { Susceptibility } \\
\text { Index only }\end{array}$ & $\begin{array}{c}\text { Susceptibility } \\
\text { Index, blue collar } \\
+ \text { demographics }\end{array}$ & $\begin{array}{l}\text { Susceptibility } \\
\text { Index } \\
+ \text { all controls } \\
\end{array}$ \\
\hline \multicolumn{4}{|l|}{$\begin{array}{l}\text { Job-related initial conditions } \\
\end{array}$} \\
\hline Susceptibility Index percentile (in 10s) & $\begin{array}{l}0.0090^{* * *} \\
(0.000)\end{array}$ & $\begin{array}{l}0.0046 \\
(0.000)\end{array}$ & $\begin{array}{r}0.0024 \\
(0.000)\end{array}$ \\
\hline \multirow[t]{2}{*}{ Blue collar } & -- & $0.04106^{* *}$ & 0.03445 \\
\hline & -- & $(0.021)$ & $(0.024)$ \\
\hline \multirow[t]{2}{*}{ Self-employed } & -- & -- & -0.04511 \\
\hline & -- & -- & $(0.029)$ \\
\hline \multirow[t]{2}{*}{ Employer-covered health insurance } & -- & -- & $-0.11696^{* * *}$ \\
\hline & -- & -- & $(0.023)$ \\
\hline \multirow[t]{2}{*}{ Retiree health insurance } & -- & -- & $0.23848 * * *$ \\
\hline & -- & -- & $(0.020)$ \\
\hline \multirow[t]{2}{*}{ Previous DB } & -- & -- & 0.03222 \\
\hline & -- & -- & $(0.022)$ \\
\hline \multirow[t]{2}{*}{ DB } & -- & -- & $-0.11030 * * *$ \\
\hline & -- & -- & $(0.032)$ \\
\hline \multirow[t]{2}{*}{ DC } & -- & -- & -0.01274 \\
\hline & -- & -- & $(0.019)$ \\
\hline \multirow[t]{2}{*}{ Job tenure } & -- & -- & -0.00113 \\
\hline & -- & -- & $(0.001)$ \\
\hline \multirow[t]{2}{*}{ Job tenure $\mathrm{x}$ DB } & -- & -- & $0.00759 * * *$ \\
\hline & -- & -- & $(0.002)$ \\
\hline \multicolumn{4}{|l|}{ Wealth-related initial conditions } \\
\hline \multirow[t]{2}{*}{ Current earnings } & -- & -- & -0.00038 \\
\hline & -- & -- & $(0.000)$ \\
\hline \multirow{2}{*}{ Pension income } & -- & -- & 0.00172 \\
\hline & -- & -- & $(0.001)$ \\
\hline \multirow[t]{2}{*}{ Financial wealth } & -- & -- & -0.00001 \\
\hline & -- & -- & $(0.000)$ \\
\hline \multicolumn{4}{|l|}{ Health-related initial conditions } \\
\hline \multirow[t]{2}{*}{ Health index } & -- & -- & $0.03820 * * *$ \\
\hline & -- & -- & $(0.008)$ \\
\hline \multicolumn{4}{|l|}{ Family-related initial conditions } \\
\hline \multirow[t]{2}{*}{ Married } & -- & -- & -0.02581 \\
\hline & -- & -- & $(0.029)$ \\
\hline \multirow[t]{2}{*}{ Presence of resident child } & -- & -- & 0.01329 \\
\hline & -- & -- & $(0.022)$ \\
\hline \multirow[t]{2}{*}{ Spouse's current earnings } & -- & -- & $0.00152^{* * *}$ \\
\hline & -- & -- & $(0.000)$ \\
\hline \multirow[t]{2}{*}{ Spouse covers health insurance } & -- & -- & 0.01036 \\
\hline & -- & -- & $(0.026)$ \\
\hline
\end{tabular}




\begin{tabular}{|c|c|c|c|}
\hline Variables & $\begin{array}{l}\text { Susceptibility } \\
\text { Index only }\end{array}$ & $\begin{array}{c}\text { Susceptibility } \\
\text { Index, blue collar } \\
+ \text { demographics }\end{array}$ & $\begin{array}{l}\text { Susceptibility } \\
\text { Index } \\
+ \text { all controls } \\
\end{array}$ \\
\hline \multirow[t]{2}{*}{ Spouse works } & -- & -- & $0.05451 * *$ \\
\hline & -- & -- & $(0.027)$ \\
\hline \multirow[t]{2}{*}{ Spouse is in fair or poor health } & -- & -- & -0.02993 \\
\hline & -- & -- & $(0.025)$ \\
\hline \multicolumn{4}{|l|}{ Job-related shocks } \\
\hline \multirow[t]{2}{*}{ Different employer } & -- & -- & $-0.09864 * * *$ \\
\hline & -- & -- & $(0.033)$ \\
\hline \multirow[t]{2}{*}{ Involuntary job loss } & -- & -- & $0.25161^{* * *}$ \\
\hline & -- & -- & $(0.025)$ \\
\hline \multirow[t]{2}{*}{ New job after involuntary job loss } & -- & -- & $-0.30781 * * *$ \\
\hline & -- & -- & $(0.045)$ \\
\hline \multirow[t]{2}{*}{ Partially retires } & -- & -- & 0.00195 \\
\hline & -- & -- & $(0.021)$ \\
\hline \multicolumn{4}{|l|}{ Wealth-related shocks } \\
\hline \multirow[t]{2}{*}{ Financial gain of at least $40 \%$} & -- & -- & $-0.05602 * * *$ \\
\hline & -- & -- & $(0.019)$ \\
\hline \multirow[t]{2}{*}{ Financial loss of at least $40 \%$} & -- & -- & -0.01326 \\
\hline & -- & -- & $(0.022)$ \\
\hline \multicolumn{4}{|l|}{ Health-related shocks } \\
\hline \multirow[t]{2}{*}{ Health index difference } & -- & -- & $0.05942 * * *$ \\
\hline & -- & -- & $(0.010)$ \\
\hline \multirow[t]{2}{*}{$\begin{array}{l}\text { Retiree health insurance } x \text { health index } \\
\text { difference }\end{array}$} & -- & -- & $-0.05663 * * *$ \\
\hline & -- & -- & $(0.016)$ \\
\hline \multicolumn{4}{|l|}{ Family-related shocks } \\
\hline \multirow[t]{2}{*}{ Marital status change } & -- & -- & $-0.07385 * * *$ \\
\hline & -- & -- & $(0.023)$ \\
\hline \multirow[t]{2}{*}{ Resident child leaves home } & -- & -- & -0.02084 \\
\hline & -- & -- & $(0.028)$ \\
\hline \multirow[t]{2}{*}{ Spouse retires } & -- & -- & $0.07015 * * *$ \\
\hline & -- & -- & $(0.021)$ \\
\hline \multirow[t]{2}{*}{ Spouse continues work } & -- & -- & $-0.12583 * * *$ \\
\hline & -- & -- & $(0.024)$ \\
\hline Demographic controls? & No & Yes & Yes \\
\hline Number of observations & 5,202 & 5,201 & 4,434 \\
\hline
\end{tabular}

Note: ${ }^{* *} \mathrm{p}<0.01,{ }^{* * *} \mathrm{p}<0.001$.

Source: Authors' estimates from the Health and Retirement Study, 1992-2012 waves. 
Table 3B. Probit Regression Estimating Retirement by Age 65

\begin{tabular}{|c|c|c|c|}
\hline Variables & $\begin{array}{l}\text { Susceptibility } \\
\text { Index only }\end{array}$ & $\begin{array}{c}\text { Susceptibility } \\
\text { Index, blue collar } \\
+ \text { demographics }\end{array}$ & $\begin{array}{l}\text { Susceptibility } \\
\text { Index } \\
+ \text { all controls }\end{array}$ \\
\hline \multicolumn{4}{|l|}{ Job-related initial conditions } \\
\hline Susceptibility Index percentile (in 10s) & $\begin{array}{l}0.0117^{* * *} \\
(0.000)\end{array}$ & $\begin{array}{l}0.0079^{* *} \\
(0.000)\end{array}$ & $\begin{array}{l}0.0071^{* *} \\
(0.000)\end{array}$ \\
\hline Blue collar & -- & $\begin{array}{c}0.04137^{* *} \\
(0.019)\end{array}$ & $\begin{array}{r}0.02550 \\
(0.021)\end{array}$ \\
\hline Self-employed & $\begin{array}{l}-- \\
--\end{array}$ & $\begin{array}{l}-- \\
--\end{array}$ & $\begin{array}{r}-0.01285 \\
(0.026)\end{array}$ \\
\hline Employer-covered health insurance & $\begin{array}{l}-- \\
--\end{array}$ & $\begin{array}{l}-- \\
--\end{array}$ & $\begin{array}{c}-0.10238^{* * * *} \\
(0.020)\end{array}$ \\
\hline Retiree health insurance & $\begin{array}{l}-- \\
--\end{array}$ & $\begin{array}{l}-- \\
--\end{array}$ & $\begin{array}{l}0.24798^{* * *} \\
(0.018)\end{array}$ \\
\hline Previous DB & $\begin{array}{l}-- \\
--\end{array}$ & $\begin{array}{l}-- \\
--\end{array}$ & $\begin{array}{c}0.04368^{* *} \\
(0.020)\end{array}$ \\
\hline DB & $\begin{array}{l}-- \\
--\end{array}$ & $\begin{array}{l}-- \\
--\end{array}$ & $\begin{array}{c}-0.09600^{* * * *} \\
(0.030)\end{array}$ \\
\hline DC & $\begin{array}{l}-- \\
--\end{array}$ & $\begin{array}{l}-- \\
--\end{array}$ & $\begin{array}{r}0.01428 \\
(0.017)\end{array}$ \\
\hline Job tenure & $\begin{array}{l}-- \\
--\end{array}$ & $\begin{array}{l}-- \\
--\end{array}$ & $\begin{array}{r}-0.00132 \\
(0.001)\end{array}$ \\
\hline Job tenure $\mathrm{x}$ DB & $\begin{array}{l}-- \\
--\end{array}$ & $\begin{array}{l}-- \\
--\end{array}$ & $\begin{array}{l}0.00699^{* * *} \\
(0.001)\end{array}$ \\
\hline Wealth-related initial conditions & & & \\
\hline Current earnings & $\begin{array}{l}-- \\
--\end{array}$ & $\begin{array}{l}-- \\
--\end{array}$ & $\begin{array}{r}-0.00024 \\
(0.000)\end{array}$ \\
\hline Pension income & $\begin{array}{l}-- \\
--\end{array}$ & $\begin{array}{l}-- \\
--\end{array}$ & $\begin{array}{r}0.00023 \\
(0.001)\end{array}$ \\
\hline Financial wealth & $\begin{array}{l}-- \\
--\end{array}$ & $\begin{array}{l}-- \\
--\end{array}$ & $\begin{array}{c}-0.00004^{* *} \\
(0.000)\end{array}$ \\
\hline Health-related initial conditions & & & \\
\hline Health index & $\begin{array}{l}-- \\
--\end{array}$ & $\begin{array}{l}-- \\
--\end{array}$ & $\begin{array}{l}0.02624 * * * \\
(0.007)\end{array}$ \\
\hline Family-related initial conditions & & & \\
\hline Married & $\begin{array}{l}-- \\
--\end{array}$ & $\begin{array}{l}-- \\
--\end{array}$ & $\begin{array}{r}0.02580 \\
(0.026)\end{array}$ \\
\hline Presence of resident child & $\begin{array}{l}-- \\
--\end{array}$ & $\begin{array}{l}-- \\
--\end{array}$ & $\begin{array}{r}0.00784 \\
(0.021)\end{array}$ \\
\hline Spouse's current earnings & $\begin{array}{l}-- \\
--\end{array}$ & $\begin{array}{l}-- \\
--\end{array}$ & $\begin{array}{c}0.00084^{* *} \\
(0.000)\end{array}$ \\
\hline Spouse covers health insurance & $\begin{array}{l}-- \\
--\end{array}$ & $\begin{array}{l}-- \\
--\end{array}$ & $\begin{array}{r}0.02891 \\
(0.023)\end{array}$ \\
\hline Spouse works & $\begin{array}{l}-- \\
--\end{array}$ & $\begin{array}{l}-- \\
--\end{array}$ & $\begin{array}{r}0.02345 \\
(0.024)\end{array}$ \\
\hline
\end{tabular}

-cont'd- 


\begin{tabular}{|c|c|c|c|}
\hline Variables & $\begin{array}{l}\text { Susceptibility } \\
\text { Index only }\end{array}$ & $\begin{array}{c}\text { Susceptibility } \\
\text { Index, blue collar } \\
+ \text { demographics }\end{array}$ & $\begin{array}{l}\text { Susceptibility } \\
\text { Index } \\
+ \text { all controls } \\
\end{array}$ \\
\hline \multirow[t]{2}{*}{ Spouse is in fair or poor health } & -- & -- & -0.00960 \\
\hline & -- & -- & $(0.023)$ \\
\hline \multicolumn{4}{|l|}{ Job-related shocks } \\
\hline \multirow[t]{2}{*}{ Different employer } & -- & -- & $-0.09162 * * *$ \\
\hline & -- & -- & $(0.028)$ \\
\hline \multirow[t]{2}{*}{ Involuntary job loss } & -- & -- & $0.17871^{* * *}$ \\
\hline & -- & -- & $(0.019)$ \\
\hline \multirow[t]{2}{*}{ New job after involuntary job loss } & -- & -- & $-0.24658 * * *$ \\
\hline & -- & -- & $(0.056)$ \\
\hline \multirow[t]{2}{*}{ Partially retires } & -- & -- & $-0.06030 * * *$ \\
\hline & -- & -- & $(0.018)$ \\
\hline \multicolumn{4}{|l|}{ Wealth-related shocks } \\
\hline \multirow[t]{2}{*}{ Financial gain of at least $40 \%$} & -- & -- & $-0.04937 * * *$ \\
\hline & -- & -- & $(0.019)$ \\
\hline \multirow[t]{2}{*}{ Financial loss of at least $40 \%$} & -- & -- & $0.03529 *$ \\
\hline & -- & -- & $(0.021)$ \\
\hline \multicolumn{4}{|l|}{ Health-related shocks } \\
\hline \multirow[t]{2}{*}{ Health index difference } & -- & -- & $0.03153^{* * *}$ \\
\hline & -- & -- & $(0.008)$ \\
\hline \multirow[t]{2}{*}{$\begin{array}{l}\text { Retiree health insurance } x \text { health index } \\
\text { difference }\end{array}$} & -- & -- & $-0.04032 * * *$ \\
\hline & -- & -- & $(0.014)$ \\
\hline \multicolumn{4}{|l|}{ Family-related shocks } \\
\hline \multirow[t]{2}{*}{ Marital status change } & -- & -- & $-0.08097 * * *$ \\
\hline & -- & -- & $(0.020)$ \\
\hline \multirow[t]{2}{*}{ Resident child leaves home } & -- & -- & $-0.05929 * *$ \\
\hline & -- & -- & $(0.027)$ \\
\hline \multirow[t]{2}{*}{ Spouse retires } & -- & -- & 0.01236 \\
\hline & -- & -- & $(0.018)$ \\
\hline \multirow[t]{2}{*}{ Spouse continues work } & -- & -- & $-0.10838 * * *$ \\
\hline & -- & -- & $(0.022)$ \\
\hline Demographic controls? & No & Yes & Yes \\
\hline Number of observations & 5,202 & 5,201 & 4,501 \\
\hline
\end{tabular}

Note: ${ }^{*} \mathrm{p}<0.05,{ }^{* *} \mathrm{p}<0.01,{ }^{* * *} \mathrm{p}<0.001$.

Source: Authors' estimates from the Health and Retirement Study, 1992-2012 waves. 
Table 3C. Probit Regression Estimating Retirement by Age 67

\begin{tabular}{|c|c|c|c|}
\hline Variables & $\begin{array}{l}\text { Susceptibility } \\
\text { Index only }\end{array}$ & $\begin{array}{c}\text { Susceptibility } \\
\text { Index, blue collar } \\
+ \text { demographics }\end{array}$ & $\begin{array}{l}\text { Susceptibility } \\
\text { Index } \\
+ \text { all controls } \\
\end{array}$ \\
\hline \multicolumn{4}{|l|}{ Job-related initial conditions } \\
\hline Susceptibility Index percentile (in 10s) & $\begin{array}{l}0.0111^{* * * *} \\
(0.000)\end{array}$ & $\begin{array}{l}0.0080^{* * * *} \\
(0.000)\end{array}$ & $\begin{array}{l}0.0074 * * * \\
(0.000)\end{array}$ \\
\hline Blue collar & $\begin{array}{l}-- \\
--\end{array}$ & $\begin{array}{c}0.02915 * \\
(0.015)\end{array}$ & $\begin{array}{r}0.01574 \\
(0.016)\end{array}$ \\
\hline Self-employed & $\begin{array}{l}-- \\
--\end{array}$ & -- & $\begin{array}{r}-0.00769 \\
(0.019)\end{array}$ \\
\hline Employer-covered health insurance & $\begin{array}{l}-- \\
--\end{array}$ & $\begin{array}{l}-- \\
--\end{array}$ & $\begin{array}{c}-0.04217^{* * * *} \\
(0.014)\end{array}$ \\
\hline Retiree health insurance & $\begin{array}{l}-- \\
--\end{array}$ & $\begin{array}{l}-- \\
--\end{array}$ & $\begin{array}{l}0.12719 * * * \\
(0.014)\end{array}$ \\
\hline Previous DB & $\begin{array}{l}-- \\
--\end{array}$ & -- & $\begin{array}{l}0.03237 * * \\
(0.014)\end{array}$ \\
\hline DB & $\begin{array}{l}-- \\
--\end{array}$ & $\begin{array}{l}-- \\
--\end{array}$ & $\begin{array}{c}-0.04951^{* *} \\
(0.022)\end{array}$ \\
\hline DC & -- & $\begin{array}{l}-- \\
--\end{array}$ & $\begin{array}{r}0.01919 \\
(0.012)\end{array}$ \\
\hline Job tenure & $\begin{array}{l}-- \\
--\end{array}$ & $\begin{array}{l}-- \\
--\end{array}$ & $\begin{array}{r}-0.00092 \\
(0.001)\end{array}$ \\
\hline Job tenure x DB & $\begin{array}{l}-- \\
--\end{array}$ & $\begin{array}{l}-- \\
--\end{array}$ & $\begin{array}{c}0.00396 * * * \\
(0.001)\end{array}$ \\
\hline Wealth-related initial conditions & & & \\
\hline Current earnings & $\begin{array}{l}-- \\
--\end{array}$ & $\begin{array}{l}-- \\
--\end{array}$ & $\begin{array}{r}-0.00020 \\
(0.000)\end{array}$ \\
\hline Pension income & $\begin{array}{l}-- \\
--\end{array}$ & $\begin{array}{l}-- \\
--\end{array}$ & $\begin{array}{r}-0.00028 \\
(0.000)\end{array}$ \\
\hline Financial wealth & $\begin{array}{l}-- \\
--\end{array}$ & $\begin{array}{l}-- \\
--\end{array}$ & $\begin{array}{r}-0.00002 \\
(0.000)\end{array}$ \\
\hline Health-related initial conditions & & & \\
\hline Health index & -- & -- & $\begin{array}{c}0.00867^{*} \\
(0.005)\end{array}$ \\
\hline Family-related initial conditions & & & \\
\hline Married & $\begin{array}{l}-- \\
--\end{array}$ & $\begin{array}{l}-- \\
--\end{array}$ & $\begin{array}{r}-0.00727 \\
(0.018)\end{array}$ \\
\hline Presence of resident child & $\begin{array}{l}-- \\
--\end{array}$ & $\begin{array}{l}-- \\
--\end{array}$ & $\begin{array}{r}0.02016 \\
(0.015)\end{array}$ \\
\hline Spouse's current earnings & $\begin{array}{l}-- \\
--\end{array}$ & $\begin{array}{l}-- \\
--\end{array}$ & $\begin{array}{r}0.00022 \\
(0.000)\end{array}$ \\
\hline Spouse covers health insurance & $\begin{array}{l}-- \\
--\end{array}$ & $\begin{array}{l}-- \\
--\end{array}$ & $\begin{array}{r}0.00883 \\
(0.016)\end{array}$ \\
\hline Spouse works & $\begin{array}{l}-- \\
--\end{array}$ & $\begin{array}{l}-- \\
--\end{array}$ & $\begin{array}{r}0.04026^{* *} \\
(0.017)\end{array}$ \\
\hline
\end{tabular}

-cont'd- 


\begin{tabular}{|c|c|c|c|}
\hline Variables & $\begin{array}{l}\text { Susceptibility } \\
\text { Index only }\end{array}$ & $\begin{array}{c}\text { Susceptibility } \\
\text { Index, blue collar } \\
+ \text { demographics }\end{array}$ & $\begin{array}{c}\text { Susceptibility } \\
\text { Index } \\
+ \text { all controls } \\
\end{array}$ \\
\hline Spouse is in fair or poor health & -- & -- & -0.00294 \\
\hline Job-related shocks & -- & -- & $(0.017)$ \\
\hline Different employer & $\begin{array}{l}-- \\
--\end{array}$ & $\begin{array}{l}-- \\
--\end{array}$ & $\begin{array}{l}-0.05817^{* * *} \\
(0.021)\end{array}$ \\
\hline Involuntary job loss & $\begin{array}{l}-- \\
--\end{array}$ & $\begin{array}{l}-- \\
--\end{array}$ & $\begin{array}{l}0.10752^{* * *} \\
(0.012)\end{array}$ \\
\hline New job after involuntary job loss & $\begin{array}{l}-- \\
--\end{array}$ & $\begin{array}{l}-- \\
--\end{array}$ & $\begin{array}{l}-0.21562^{* * *} \\
(0.055)\end{array}$ \\
\hline Partially retires & $\begin{array}{l}-- \\
--\end{array}$ & $\begin{array}{l}-- \\
--\end{array}$ & $\begin{array}{c}-0.09483^{* * *} \\
(0.014)\end{array}$ \\
\hline Wealth-related shocks & & & \\
\hline Financial gain of at least $40 \%$ & $\begin{array}{l}-- \\
--\end{array}$ & $\begin{array}{l}-- \\
--\end{array}$ & $\begin{array}{l}-0.02694^{* *} \\
(0.013)\end{array}$ \\
\hline Financial loss of at least $40 \%$ & $\begin{array}{l}-- \\
--\end{array}$ & $\begin{array}{l}-- \\
--\end{array}$ & $\begin{array}{r}0.01651 \\
(0.016)\end{array}$ \\
\hline Health-related shocks & & & \\
\hline Health index difference & $\begin{array}{l}-- \\
--\end{array}$ & $\begin{array}{l}-- \\
--\end{array}$ & $\begin{array}{r}0.00880 \\
(0.005)\end{array}$ \\
\hline $\begin{array}{l}\text { Retiree health insurance } \mathrm{x} \text { health index } \\
\text { difference }\end{array}$ & -- & -- & $-0.02113^{* *}$ \\
\hline Family-related shocks & -- & -- & $(0.010)$ \\
\hline Marital status change & $\begin{array}{l}-- \\
--\end{array}$ & $\begin{array}{l}-- \\
--\end{array}$ & $\begin{array}{l}-0.04952^{* * *} \\
(0.015)\end{array}$ \\
\hline Resident child leaves home & $\begin{array}{l}-- \\
--\end{array}$ & $\begin{array}{l}-- \\
--\end{array}$ & $\begin{array}{c}-0.04117^{*} \\
(0.021)\end{array}$ \\
\hline Spouse retires & $\begin{array}{l}-- \\
--\end{array}$ & $\begin{array}{l}-- \\
--\end{array}$ & $\begin{array}{c}0.02221 * \\
(0.012)\end{array}$ \\
\hline Spouse continues work & $\begin{array}{l}-- \\
--\end{array}$ & $\begin{array}{l}-- \\
--\end{array}$ & $\begin{array}{l}-0.05677^{* * *} \\
(0.016)\end{array}$ \\
\hline Demographic controls? & No & Yes & Yes \\
\hline Number of observations & 5,202 & 5,201 & 4,560 \\
\hline
\end{tabular}

Note: * $\mathrm{p}<0.05,{ }^{* *} \mathrm{p}<0.01,{ }^{* * *} \mathrm{p}<0.001$.

Source: Authors' estimates from the Health and Retirement Study, 1992-2012 waves. 
Table 4. Counterfactual Predictions of Retiring before 67 with 25th Percentile Susceptibility Index

\begin{tabular}{lccc} 
Susceptibility Index percentiles & Original probability & Adjusted probability & Percent change \\
\hline $1-10$ & $77.9 \%$ & $79.9 \%$ & $2.5 \%$ \\
$11-20$ & 78.9 & 79.9 & 1.2 \\
$21-30$ & 81.3 & 81.2 & -0.1 \\
$31-40$ & 80.9 & 79.6 & -1.6 \\
$41-50$ & 81.5 & 79.6 & -2.4 \\
$51-60$ & 83.3 & 80.4 & -3.4 \\
$61-70$ & 83.6 & 79.9 & -4.5 \\
$71-80$ & 86.3 & 82.0 & -5.0 \\
$81-90$ & 86.6 & 81.4 & -6.0 \\
$91-100$ & 88.1 & 82.4 & -6.5 \\
\hline
\end{tabular}

Source: Authors’ estimates from the Health and Retirement Study, 1992-2012 waves. 
Table 5. Probit Regression Estimating Disability Receipt by 65

\begin{tabular}{|c|c|c|c|}
\hline Variables & $\begin{array}{l}\text { Susceptibility } \\
\text { Index only }\end{array}$ & $\begin{array}{c}\text { Susceptibility } \\
\text { Index, blue collar } \\
+ \text { demographics }\end{array}$ & $\begin{array}{l}\text { Susceptibility } \\
\text { Index } \\
+ \text { all controls } \\
\end{array}$ \\
\hline \multicolumn{4}{|l|}{ Job-related initial conditions } \\
\hline Susceptibility Index percentile (in 10s) & $\begin{array}{l}0.0057^{* * *} \\
(0.000)\end{array}$ & $\begin{array}{c}0.00031^{* *} \\
(0.000)\end{array}$ & $\begin{array}{c}0.0002 \\
(0.000)\end{array}$ \\
\hline Blue collar & $\begin{array}{l}-- \\
--\end{array}$ & $\begin{array}{r}0.00257 \\
(0.008)\end{array}$ & $\begin{array}{r}0.01104 \\
(0.009)\end{array}$ \\
\hline Self-employed & $\begin{array}{l}-- \\
--\end{array}$ & $\begin{array}{l}-- \\
--\end{array}$ & $\begin{array}{c}-0.01578 * \\
(0.008)\end{array}$ \\
\hline Employer-covered health insurance & $\begin{array}{l}-- \\
--\end{array}$ & $\begin{array}{l}-- \\
--\end{array}$ & $\begin{array}{r}-0.00321 \\
(0.008)\end{array}$ \\
\hline Retiree health insurance & $\begin{array}{l}-- \\
--\end{array}$ & $\begin{array}{l}-- \\
--\end{array}$ & $\begin{array}{r}-0.00943 \\
(0.008)\end{array}$ \\
\hline Previous DB & $\begin{array}{l}-- \\
--\end{array}$ & $\begin{array}{l}-- \\
--\end{array}$ & $\begin{array}{r}-0.00395 \\
(0.008)\end{array}$ \\
\hline DB & $\begin{array}{l}-- \\
--\end{array}$ & $\begin{array}{l}-- \\
--\end{array}$ & $\begin{array}{c}-0.02442^{* *} \\
(0.011)\end{array}$ \\
\hline DC & $\begin{array}{l}-- \\
--\end{array}$ & $\begin{array}{l}-- \\
--\end{array}$ & $\begin{array}{r}0.00289 \\
(0.007)\end{array}$ \\
\hline Job tenure & $\begin{array}{l}-- \\
--\end{array}$ & $\begin{array}{l}-- \\
--\end{array}$ & $\begin{array}{c}-0.00095 * * \\
(0.000)\end{array}$ \\
\hline Job tenure $\mathrm{x}$ DB & $\begin{array}{l}-- \\
--\end{array}$ & $\begin{array}{l}-- \\
--\end{array}$ & $\begin{array}{r}0.00094 \\
(0.001)\end{array}$ \\
\hline Wealth-related initial conditions & & & \\
\hline Current earnings & $\begin{array}{l}-- \\
--\end{array}$ & $\begin{array}{l}-- \\
--\end{array}$ & $\begin{array}{r}-0.00000 \\
(0.000)\end{array}$ \\
\hline Pension income & $\begin{array}{l}-- \\
--\end{array}$ & $\begin{array}{l}-- \\
--\end{array}$ & $\begin{array}{c}-0.00000 * * \\
(0.000)\end{array}$ \\
\hline Financial wealth & $\begin{array}{l}-- \\
--\end{array}$ & $\begin{array}{l}-- \\
--\end{array}$ & $\begin{array}{r}-0.00004 \\
(0.000)\end{array}$ \\
\hline Health-related initial conditions & & & \\
\hline Health index & $\begin{array}{l}-- \\
--\end{array}$ & $\begin{array}{l}-- \\
--\end{array}$ & $\begin{array}{l}0.02421^{* * *} \\
(0.003)\end{array}$ \\
\hline Family-related initial conditions & & & \\
\hline Married & $\begin{array}{l}-- \\
--\end{array}$ & $\begin{array}{l}-- \\
--\end{array}$ & $\begin{array}{r}-0.00681 \\
(0.010)\end{array}$ \\
\hline Presence of resident child & $\begin{array}{l}-- \\
--\end{array}$ & $\begin{array}{l}-- \\
--\end{array}$ & $\begin{array}{r}0.01182 \\
(0.008)\end{array}$ \\
\hline Spouse's current earnings & $\begin{array}{l}-- \\
--\end{array}$ & $\begin{array}{l}-- \\
--\end{array}$ & $\begin{array}{r}-0.00000 \\
(0.000)\end{array}$ \\
\hline Spouse covers health insurance & $\begin{array}{l}-- \\
--\end{array}$ & $\begin{array}{l}-- \\
--\end{array}$ & $\begin{array}{c}-0.02033^{* * *} \\
(0.008)\end{array}$ \\
\hline Spouse works & $\begin{array}{l}-- \\
--\end{array}$ & $\begin{array}{l}-- \\
--\end{array}$ & $\begin{array}{r}0.01400 \\
(0.010)\end{array}$ \\
\hline
\end{tabular}

-cont'd- 


\begin{tabular}{|c|c|c|c|}
\hline Variables & $\begin{array}{l}\text { Susceptibility } \\
\text { Index only }\end{array}$ & $\begin{array}{c}\text { Susceptibility } \\
\text { Index, blue collar } \\
+ \text { demographics }\end{array}$ & $\begin{array}{l}\text { Susceptibility } \\
\text { Index } \\
+ \text { all controls } \\
\end{array}$ \\
\hline \multirow[t]{2}{*}{ Spouse is in fair or poor health } & -- & -- & -0.00491 \\
\hline & -- & -- & $(0.008)$ \\
\hline \multicolumn{4}{|l|}{ Job-related shocks } \\
\hline \multirow{2}{*}{ Different employer } & -- & -- & $-0.02903 * * *$ \\
\hline & -- & -- & $(0.008)$ \\
\hline \multirow[t]{2}{*}{ Involuntary job loss } & -- & -- & $0.02017 *$ \\
\hline & -- & -- & $(0.011)$ \\
\hline \multirow[t]{2}{*}{ New job after involuntary job loss } & -- & -- & $-0.02271^{*}$ \\
\hline & -- & -- & $(0.013)$ \\
\hline \multirow[t]{2}{*}{ Partially retires } & -- & -- & $-0.02181 * * *$ \\
\hline & -- & -- & $(0.006)$ \\
\hline \multicolumn{4}{|l|}{ Wealth-related shocks } \\
\hline \multirow[t]{2}{*}{ Financial gain of at least $40 \%$} & -- & -- & -0.00703 \\
\hline & -- & -- & $(0.008)$ \\
\hline \multirow[t]{2}{*}{ Financial loss of at least $40 \%$} & -- & -- & 0.01544 \\
\hline & -- & -- & $(0.010)$ \\
\hline \multicolumn{4}{|l|}{ Health-related shocks } \\
\hline \multirow[t]{2}{*}{ Health index difference } & -- & -- & $0.02358 * * *$ \\
\hline & -- & -- & $(0.003)$ \\
\hline \multirow[t]{2}{*}{$\begin{array}{l}\text { Retiree health insurance } x \text { health index } \\
\text { difference }\end{array}$} & -- & -- & 0.00049 \\
\hline & -- & -- & $(0.005)$ \\
\hline \multicolumn{4}{|l|}{ Family-related shocks } \\
\hline \multirow[t]{2}{*}{ Marital status change } & -- & -- & $-0.01349 * *$ \\
\hline & -- & -- & $(0.006)$ \\
\hline \multirow[t]{2}{*}{ Resident child leaves home } & -- & -- & -0.01081 \\
\hline & -- & -- & $(0.008)$ \\
\hline \multirow[t]{2}{*}{ Spouse retires } & -- & -- & -0.00368 \\
\hline & -- & -- & $(0.007)$ \\
\hline \multirow[t]{2}{*}{ Spouse continues work } & -- & -- & $-0.01869 * *$ \\
\hline & -- & -- & $(0.009)$ \\
\hline Demographic controls? & No & Yes & Yes \\
\hline Number of observations & 5,202 & 5,201 & 4,560 \\
\hline
\end{tabular}

Note: * $\mathrm{p}<0.05,{ }^{* *} \mathrm{p}<0.01,{ }^{* * *} \mathrm{p}<0.001$.

Source: Authors' estimates from the Health and Retirement Study, 1992-2012 waves. 
Figure 1. Sampling of Occupations and Their Susceptibility Index Percentiles

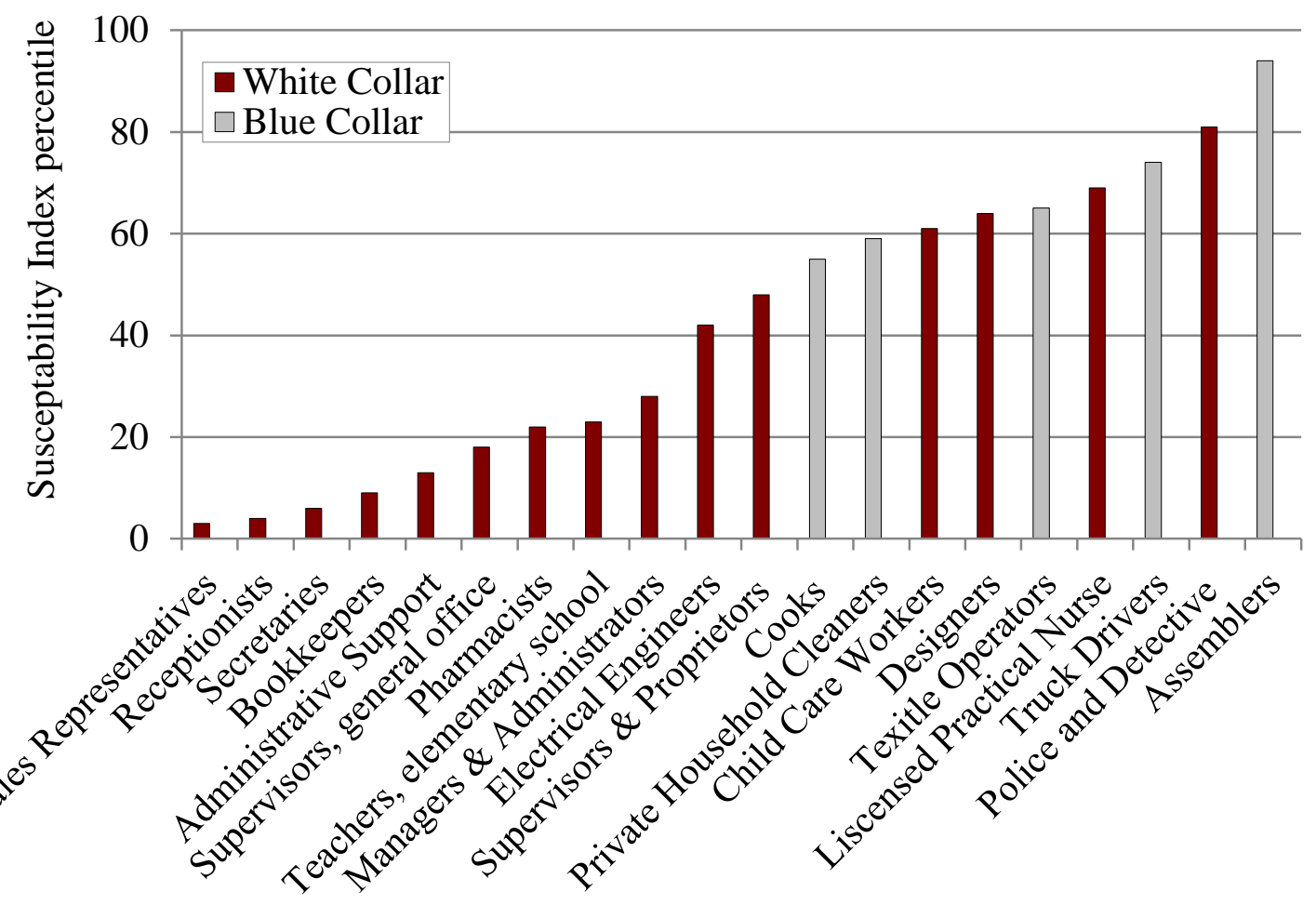

Source: Authors' review of literature and authors calculation using the Susceptibility Index (see text and references). 


\section{Appendix}

Table A1. Assignment of Cognitive Abilities

\begin{tabular}{lc}
\hline Ability & Shows early decline? \\
\hline Verbal abilities & \\
Oral comprehension & No \\
Written comprehension & No \\
Oral expression & No \\
Written expression & No \\
Idea generation and reasoning abilities & \\
Fluency of ideas & Yes \\
Originality & No \\
Problem sensitivity & No \\
Deductive reasoning & Yes \\
Inductive reasoning & Yes \\
Information ordering & Yes \\
Category flexibility & No \\
Quantitative abilities & \\
Mathematical reasoning & No \\
Number facility & No \\
Memory & \\
Memorization & Yes \\
Perceptual abilities & \\
Speed of closure & Yes \\
Flexibility of closure & No \\
Perceptual speed & Yes \\
Spatial abilities & Yes \\
Spatial orientation & Yes \\
Visualization & \\
Attentiveness & No \\
Selective attention & Yes \\
Time sharing & \\
\hline
\end{tabular}

Source: Authors' review of literature (see text and references). 
Table A2. Assignment of Psychomotor Abilities

\begin{tabular}{lc}
\hline Ability & Shows early decline? \\
\hline Fine manipulative abilities & \\
Arm-hand steadiness & Yes \\
Manual dexterity & Yes \\
Finger dexterity & Yes \\
Control movement abilities & \\
Control precision & No \\
Multilimb coordination & No \\
Response orientation & No \\
Rate control & No \\
Reaction time and speed abilities & \\
Reaction time & Yes \\
Wrist-finger speed & Yes \\
Speed of limb movement & Yes \\
\hline
\end{tabular}

Source: Authors' review of literature (see text and references).

Table A3. Assignment of Physical Abilities

\begin{tabular}{lc}
\hline Ability & Shows early decline? \\
\hline Physical strength abilities & \\
Static strength (isometric strength) & No \\
Explosive strength & Yes \\
Dynamic strength & Yes \\
Trunk strength & No \\
Endurance & \\
Stamina & No \\
Flexibility, balance, and coordination & \\
Extent flexibility & Yes \\
Dynamic flexibility & Yes \\
Gross body coordination & Yes \\
Gross body equilibrium & Yes \\
\hline
\end{tabular}

Source: Authors' review of literature (see text and references). 
Table A4. Assignment of Sensory Abilities

\begin{tabular}{lc}
\hline Ability & Shows early decline? \\
\hline Visual abilities & \\
Near vision & No \\
Far vision & No \\
Visual color discrimination & No \\
Night vision & Yes \\
Peripheral vision & Yes \\
Depth perception & Yes \\
Glare sensitivity & Yes \\
Auditory and speech abilities & \\
Hearing sensitivity & No \\
Auditory attention & No \\
Sound localization & Yes \\
Speech recognition & No \\
Speech clarity & No \\
\hline
\end{tabular}

Source: Authors' review of literature (see text and references). 


\section{RECENT WORKING PAPERS FROM THE CENTER FOR RETIREMENT RESEARCH AT BOSTON COLLEGE}

Job Polarization and Labor Market Outcomes for Older, Middle-Skilled Workers Matthew S. Rutledge and Qi Guan, September 2015

What Causes Workers to Retire Before They Plan?

Alicia H. Munnell, Geoffrey T. Sanzenbacher, and Matthew S. Rutledge, September 2015

Calculating Neutral Increases in Retirement Age by Socioeconomic Status

Geoffrey T. Sanzenbacher, Anthony Webb, Candace M. Cosgrove, and Natalia S. Orlova, August 2015

How Does Occupational Access for Older Workers Differ by Education?

Matthew S. Rutledge, Steven A. Sass, and Jorge D. Ramos-Mercado, August 2015

How Much Longer Do People Need to Work?

Alicia H. Munnell, Anthony Webb, and Anqi Chen, August 2015

The Challenge of Pension Reform in Georgia: Non-Contributory Pensions and Elderly Poverty

Tamila Nutsubidze and Khatuna Nutsubidze, July 2015

The Transition from Defined Benefit to Defined Contribution Pensions: Does It Influence Elderly Poverty?

Natalia S. Orlova, Matthew S. Rutledge, and April Yanyuan Wu, July 2015

Will the Average Retirement Age Continue to Increase?

Matthew S. Rutledge, Christopher M. Gillis, and Anthony Webb, July 2015

The Role of Occupations in Differentiating Health Trajectories in Later Life

Michal Engelman and Heide Jackson, University of Wisconsin-Madison, July 2015

The Relationship Between Automatic Enrollment and DC Plan Contributions: Evidence from a National Survey of Older Workers

Barbara A. Butrica and Nadia S. Karamcheva, July 2015

Evidence of Increasing Differential Mortality: A Comparison of the HRS and SIPP Barry P. Bosworth and Kan Zhang, July 2015

Slowed or Sidelined? The Effect of “Normal” Cognitive Decline on Job Performance Among the Elderly

Anek Belbase, Mashfiqur R. Khan, Alicia H. Munnell, and Anthony Webb, June 2015

All working papers are available on the Center for Retirement Research website (http://crr.bc.edu) and can be requested by e-mail (crr@bc.edu) or phone (617-552-1762). 